\title{
PENDUGAAN PERMINTAAN MASUKAN DAN PENAWARAN KELUARAN USAHA BUDIDAYA PEMBESARAN LELE DI KOLAM (STUDI KASUS DI KABUPATEN TULUNG AGUNG, PROPINSI JAWA TIMUR)
}

\section{ESTIMATION OF INPUT DEMAND AND OUTPUT SUPPLY FOR CATFISH GROWTH OUT IN POND (A CASE STUDY IN TULUNG AGUNG REGENCY, EAST JAVA PROVINCE)}

\author{
Tajerin $^{*}$ dan M. Noor ${ }^{*}$
}

\begin{abstract}
The objective of this study was to estimate input demand and output supply for catfish growth out. The study was conducted in Tulung Agung regency, East Java from August to December 2002. Data were analyzed statistically by profit function model, using ThreeStages Least Square estimation. The results of this study showed that the catfish price was elastic and responsive to the changes of catfish seed and feed prices, but inelastic to the changes of human labor. The catfish price had positive effects on variables input demand and output supply. These positive effects were more significance than the negative effect of variables input price
\end{abstract}

Keywords: Catfish, growth out, input demand, output supply, pond

\section{Pengantar}

Dalam situasi pasca krisis ekonomi saat ini, sub sektor perikanan merupakan tumpuan harapan pemerintah yang dapat diandalkan untuk ikut berperan dalam upaya pemulihan kegiatan perekonomian yang sedang terpuruk. Salah satu komoditas budidaya air tawar yang cukup potensial adalah budidaya lele. Akhirakhir ini permintaan lele dari hasil budidaya terus meningkat dan usaha ini semakin berkembang karena dalam proses produksinya lebih banyak memanfaatkan sumberdaya yang ada dan menggunakan komponen lokal cukup besar, sementara hasil dari usaha budidaya lele berpotensi pasar domestik yang sangat besar.

Pengembangan usaha budidaya lele di Indonesia dilakukan baik secara ekstensif maupun intensif, salah satunya adalah kolam. Beberapa kelebihan dari budidaya lele dalam kolam adalah rendahnya biaya operasional dibandingkan dengan nilai ekonomi yang dihasilkan serta teknologi budidayanya yang sederhana dan mudah diadaptasikan di masyarakat petani lele secara luas.
Pada saat sekarang, Kabupaten Tulung Agung, Jawa Timur telah mengembangkan usaha budidaya lele dengan sistem kolam. Banyak petani yang berusaha budidaya dengan pertimbangan potensi sumberdaya yang tersedia cukup besar, dan lele merupakan komoditas pangan dengan harga yang cukup tinggi. Di samping itu teknologi dalam usaha budidayanya mulai dari pembenihan, pendederan hingga pembesaran telah dikuasai.

Dengan semakin berkembangnya usaha pembesaran lele dalam kolam ini, maka kebutuhan terhadap masukan produksi seperti benih lele, pakan lele dan tenaga kerja manusia akan semakin meningkat. Menghadapi fenomena demikian sebagai upaya antisipatif perlu dilakukan kajian pendugaan permintaan masukan dan penawaran keluaran untuk budidaya lele dalam kolam di Kabupaten Tulung Agung, Jawa Timur.

Penelitian ini bertujuan untuk mengkaji faktor-faktor yang mempengaruhi permintaan masukan (input) dan keluaran (output) budidaya lele dalam kolam di Kabupaten Tulung Agung, Jawa Timur.

\footnotetext{
") Staf Peneliti pada Pusat Riset Pengolahan Produk dan Sosial Ekonomi Departemen Kelautan dan Perikanan, JI. K.S. Tubun Petamburan VI PO BOX 6650, Slipi, Jakarta
} 


\section{Bahan dan Metode}

\section{Kerangka dan Model Analisis}

Pendugaan fungsi permintaan masukan dan penawaran keluaran melalui fungsi turunan sebagian besar dilakukan dengan fungsi keuntungan Cobb-Douglas (Sawit, , 1985). Perumusan fungsi keuntungan didasari oleh asumsi bahwa pelaku ekonomi melaksanakan aktivitasnya dalam rangka memaksimumkan keuntungan, dan dalam menjalankan usahanya mereka berada di posisi sebagai penerima harga (price taker).

Secara operasional, fungsi keuntungan didefenisikan sebagai suatu fungsi yang memberikan keuntungan maksimum untuk suatu tingkat harga keluaran dan harga-harga masukan tertentu (given) (Varian, 1978). Pemakaian fungsi dualistik seperti fungsi keuntungan memberikan beberapa kelebihan, antara lain fungsi ini menggunakan harga-harga sebagai peubah bebas, sehingga memudahkan dalam pengambilan keputusan dan kemungkinan adanya multikolinieriti yang lebih kecil dibanding menggunakan fungsi produksi (Biswanger, 1974).

Dalam penelitian ini digunakan model fungsi permintaan dan penawaran yang dibangun berdasarkan fungsi keuntungan yang diturunkan dari fungsi produksi Cobb-Douglas (Lau and Yotopaulus, 1971, 1972, 1979; Chand and Kaul, 1986) dengan tiga masukan tidak tetap dan dua masukan tetap, yaitu:

$$
\pi^{*}=\left(A^{*}\right) \bigcap_{i=1}^{3} P_{x i}{ }^{\prime 2} i^{*} \bigcap_{j=1}^{2} Z_{j} j^{\beta j^{*} \ldots \text { (1) }}
$$

yang dapat ditulis dalam bentuk logaritma asli menjadi:

$$
\operatorname{Ln} \pi^{*}=\operatorname{Ln} A^{*}+\sum_{i=1}^{3} \alpha_{i}^{*} \operatorname{Ln} P_{x i}^{\prime}+\sum_{j=1}^{2} \beta_{j}^{*} \operatorname{Ln} Z_{j} . . \quad \text { (2) }
$$

dimana:

$$
\begin{aligned}
A^{*} & =A^{(1-u)-1}(1-u) \sum_{i=1}^{3}(\alpha i) \\
\alpha_{i}^{*} & =-\alpha_{i}(1-u)^{-1}<0 \quad \text { untuk } \mathrm{i}=1,2,3 ; \\
\operatorname{dan} \beta_{j}^{*} & =-\beta_{j}(1-u)^{-1}<0 \quad \text { untuk } \mathrm{j}=1,2
\end{aligned}
$$

dimana:

$$
\begin{aligned}
& \pi^{*}=\text { keuntungan Output Unit Price } \\
& \text { (OUP); keuntungan jangka pendek } \\
& \text { yang dinormalkan dengan harga } \\
& \text { lele } \\
& \mathrm{A}^{*}=\text { konstanta } \\
& P_{x 1}=\text { harga benih lele yang dinormalkan } \\
& \text { dengan harga lele } \\
& P_{\times 2}=\text { harga pakan lele yang dinormalkan } \\
& \text { dengan harga lele } \\
& P_{x 3}=\text { upah tenaga kerja yang dinor- } \\
& \text { malkan dengan harga lele } \\
& Z_{1}=\text { luas kolam }\left(\mathrm{m}^{2}\right) \\
& \mathrm{Z}_{2}=\text { modal investasi (Rp.) } \\
& \alpha_{i}=\quad \text { parameter masukan peubah yang } \\
& \beta_{j}{ }^{*}=\quad \text { parameter masukan peubah yang } \\
& \text { diduga, } j=1,2,3
\end{aligned}
$$

Melalui pemakaian fungsi turunan dalam bentuk "share" menghasilkan fungsi peranan biaya (share factor), sebagai beriku:

$$
\begin{aligned}
S_{i}= & \frac{P_{i}^{*} X_{i}}{\pi^{*}}=\frac{\partial \operatorname{Ln} \pi^{*}}{\partial \operatorname{Ln} P_{i}^{*}}=\alpha_{i}+\sum_{j=1}^{n} \beta_{i j} P_{j}^{*}+\sum_{k=1}^{m} \partial_{i k} L n Z_{k}{ }^{(3)} \\
S_{i}= & \text { peranan biaya (share factor) me- } \\
& \text { rupakan rasio dari pengeluaran ma- } \\
& \text { sukan ke-i terhadap keuntungan. }
\end{aligned}
$$

Elastistitas permintaan masukan dan elastisitas penawaran dari fungsi keuntungan dapat diturunkan sebagai berikut:

1). Elastisitas permintaan masukan

a. Elatisitas permintaan harga sendiri (own price elasticty)

$$
E_{i i}=-S_{i}-1-\frac{\beta_{i i}}{S_{i}}
$$

b. Elastisitas permintaan harga silang (cross price elasticity)

$$
E_{i j}=-S_{j}-1-\frac{\beta_{i j}}{S_{i}}
$$

c. Elatisitas permintaan masukan terhadap harga keluaran

$$
E_{i y}=\sum_{i=1}^{n} S_{i}+1+\sum_{j=1}^{n} \frac{\beta_{i j}}{S_{i}}
$$

d. Elastisitas permintaan masukan terhadap masukan tetap

$$
E_{i k}=\sum_{j=1}^{n} \delta_{i k}+\operatorname{Ln} P_{i}^{*}+\rho_{k}-\frac{\delta_{i k}}{S_{i}}
$$


2). Elastisitas penawaran keluaran

a. Elastisitas penawaran keluaran terhadap harga masukan

$$
E_{y y}=-S_{i}^{*}-\sum_{J=1}^{n} \beta_{j i} /\left(1+\sum_{j=1}^{n} S_{j}\right)
$$

b. Elastisitas penawaran harga sendiri (own price elasticity of supply)

$$
E_{y y}=\sum_{i=1}^{n} S_{i}+\sum_{i=1}^{n} \sum_{j=1}^{n} \beta_{i j}\left(1+\sum_{i=1}^{n} S_{j}\right)
$$

c. Elastisitas penawaran keluaran terhadap harga masukan tetap

$$
E_{y k}=\sum_{i=1}^{n} \delta_{i k} L n P_{i}^{*}+\rho_{k}-\sum_{i=1}^{n} \delta_{i k} /\left(1+\sum_{j=1}^{n} S_{j}\right)
$$

Dari persamaan keuntungan Output Unit Price (OUP) dapat diturunkan fungsi permintaan masukan sebagai berikut:

$$
\begin{aligned}
& X_{i}=-\frac{\alpha_{i}^{* \prime} \cdot \pi^{*}}{P_{x i}^{\prime}} \\
& \operatorname{Ln} X_{i}=\operatorname{Ln}\left(-\alpha_{i}{ }^{*}\right)+\operatorname{Ln} \pi^{*}-\operatorname{Ln} P_{x i}^{\prime}
\end{aligned}
$$

dengan demikian, fungsi permintaan untuk masing-masing masukan tidak tetap adalah sebagai berikut:

$$
\text { a. Benih Lele }\left(\mathrm{X}_{1}\right) \text { : }
$$

$$
\begin{gathered}
\operatorname{Ln} X_{1}=\operatorname{Ln}\left(-\alpha_{1}^{*}\right)+\operatorname{Ln} A^{*}+\left(\alpha_{1}^{*}-1\right) \operatorname{Ln} P_{x 1}+\alpha_{2}^{*} \operatorname{Ln} P_{x 2}+\alpha_{3}^{*} \operatorname{Ln} P_{x 3} \\
+\left(1-\sum_{i=1}^{3} \alpha_{i}^{3}\right) \operatorname{Ln} P_{y}+\beta_{1}^{*} \operatorname{Ln} Z_{1}+\beta_{2}^{*} \operatorname{Ln} Z_{2} .
\end{gathered}
$$

b. Pakan Lele $\left(X_{2}\right)$ :

$$
\begin{gathered}
\operatorname{Ln} X_{2}=\operatorname{Ln}\left(-\alpha_{2}^{*}\right)+\operatorname{Ln} A^{*}+\left(\alpha_{2}^{*}-1\right) \operatorname{Ln} P_{x 2}+\alpha_{1}^{*} \operatorname{Ln} P_{x 1}+\alpha_{3}^{*} \operatorname{Ln} P_{x 3} \\
+\left(1-\sum_{i=1}^{3} \alpha_{i}^{3}\right) \operatorname{Ln} P_{y}+\beta_{1}^{*} \operatorname{Ln} Z_{1}+\beta_{2}^{*} \operatorname{Ln} Z_{2} \ldots(5)
\end{gathered}
$$

c. Tenaga Kerja Manusia $\left(\mathrm{X}_{3}\right)$ :

$$
\begin{gathered}
\operatorname{Ln} X_{3}=\operatorname{Ln}\left(-\alpha_{3}^{*}\right)+\operatorname{Ln} A^{*}+\left(\alpha_{3}^{*}-1\right) \operatorname{Ln} P_{x 3}+\alpha_{1}^{*} \operatorname{Ln} P_{x 1}+\alpha_{2}^{*} \operatorname{Ln} P_{x 2} \\
+\left(1-\sum_{i=1}^{3} \alpha_{i}^{3}\right) \operatorname{Ln} P_{y}+\beta_{1}^{*} \operatorname{Ln} Z_{1}+\beta_{2}^{*} \operatorname{Ln} Z_{2} \cdots(6)
\end{gathered}
$$

Sedangkan fungsi penawaran untuk lele adalah sebagai berikut:

$$
\begin{aligned}
& Y^{*}=\pi^{*}+\sum_{i=1}^{3} P_{x i}^{\prime} \cdot X_{i}=\pi^{*}\left(1-\sum_{i=1}^{3} \alpha_{i}^{* \prime}\right) \\
& \operatorname{Ln} Y^{*}=\operatorname{Ln} \pi^{*}+\operatorname{Ln}\left(1-\sum_{i=1}^{3} \alpha_{i}^{* \prime}\right)
\end{aligned}
$$

$$
\begin{aligned}
& =\operatorname{Ln} A^{*}+\alpha_{1}^{*} \operatorname{Ln} P_{x 1}+\alpha_{2}^{*} \operatorname{Ln} P_{x 2}+\alpha_{3}^{*} \operatorname{Ln} P_{x 3}-\sum_{i=1}^{3} \alpha_{i}^{*} \operatorname{Ln} P_{y} \\
& +\beta_{1} \operatorname{Ln} Z_{1}+\beta_{2} \operatorname{Ln} Z_{2}+\operatorname{Ln}\left(1-\sum_{i=1}^{3} \alpha_{i}^{* \prime}\right) \ldots(7)
\end{aligned}
$$

\section{Analisis data}

Berdasarkan pertimbangan bahwa model analisis diduga mempunyai $\alpha_{1}^{*}$ yang muncul dalam persamaan sehingga menyebabkan pendugaan dengan metoda Ordinary Least Square (OLS) tidak efisien, oleh karena itu pendugaan model fungsi permintaan dilakukan dalam tiga tahap dengan metoda kuadrat terkecil tiga tahap (Three-Stages Least Square). Pertama dengan OLS yang digunakan sebagai pembanding; kedua, dengan metoda efisiensi Zellner (1962) tanpa restriksi kesamaan $\alpha_{1}^{*}=\alpha_{1}^{* \prime}$; dan ketiga dengan metoda efisiensi Zellner dengan restriksi kesamaan $\alpha_{1}{ }^{*}=\alpha_{1}{ }^{*}$. Pendugaan parameter (coefficient) fungsi permintaan dan fungsi penawaran dari model yang digunakan dilakukan melalui perhitungan dengan program "Statistic Analysis System" (SAS).

\section{Penentuan lokasi dan pengambilan sampel}

Penelitian ini merupakan kajian yang dilakukan dengan menggunakan kasus di tiga kecamatan (Gondang, Sumber Gempol dan Boyolangu) Kabupaten Tulung Agung, Jawa Timur dengan satuan kasus petani lele yang memiliki usaha perikanan budidaya lele dalam kolam. Penggunaan kajian kasus dalam penelitian ini dimaksudkan untuk mendapatkan gambaran secara rinci tentang latar belakang, sifat serta karakteristik yang khas pada suatu kasus untuk dijadikan suatu hal yang bersifat umum (Natsir, 1988).

Dengan pertimbangan bahwa di Kabupaten Tulung Agung merupakan salah satu sentra produksi lele yang terbesar di Jawa Timur, maka lokasi tersebut secara sengaja (purposive) ditentukan sebagai wilayah sampel. Selanjutnya penentuan responden petani lele dilakukan dengan metoda sensus, mengingat popu- 
lasi petani lele di lokasi penelitian yang relatif sedikit, yaitu sebanyak 30 orang petani lele.

\section{Hasil dan Pembahasan}

Pendugaan fungsi peranan biaya (share factor)

Pendugaan parameter dalam penelitian ini menggunakan persamaan fungsi peranan biaya (share factor) yang merupakan turunan dari persamaan fungsi keuntungan output unit price (OUP). Sebanyak tiga persamaan fungsi peranan biaya (share factor) diduga secara simultan. Ketiga fungsi peranan biaya (share factor) adalah untuk benih lele, pakan lele dan tenaga kerja manusia. Hasil pendugaan fungsi peranan biaya (share factor) usaha budidaya lele dalam kolam di Kabupaten Tulung Agung tertera pada Table 1.

Dari Table 1 diketahui bahwa pendugaan fungsi keuntungan mempunyai nilai $R^{2}$ untuk masing-masing model berturut-turut adalah 0,854700; 0,948300; dan 0,86500. Hal ini berarti peubah bebas secara bersama-sama dapat menerangkan dengan baik keragaman dalam peubah tidak bebas (keuntungan), yakni sebesar $85,47 \%$ (model I) ; 94,83\% (model II) ; dan $94,83 \%$ (model III).

Tabel 1. Pendugaan fungsi peranan biaya (share factor) masukan tidak tetap pada usaha budidaya pembesaran lele dalam kolam

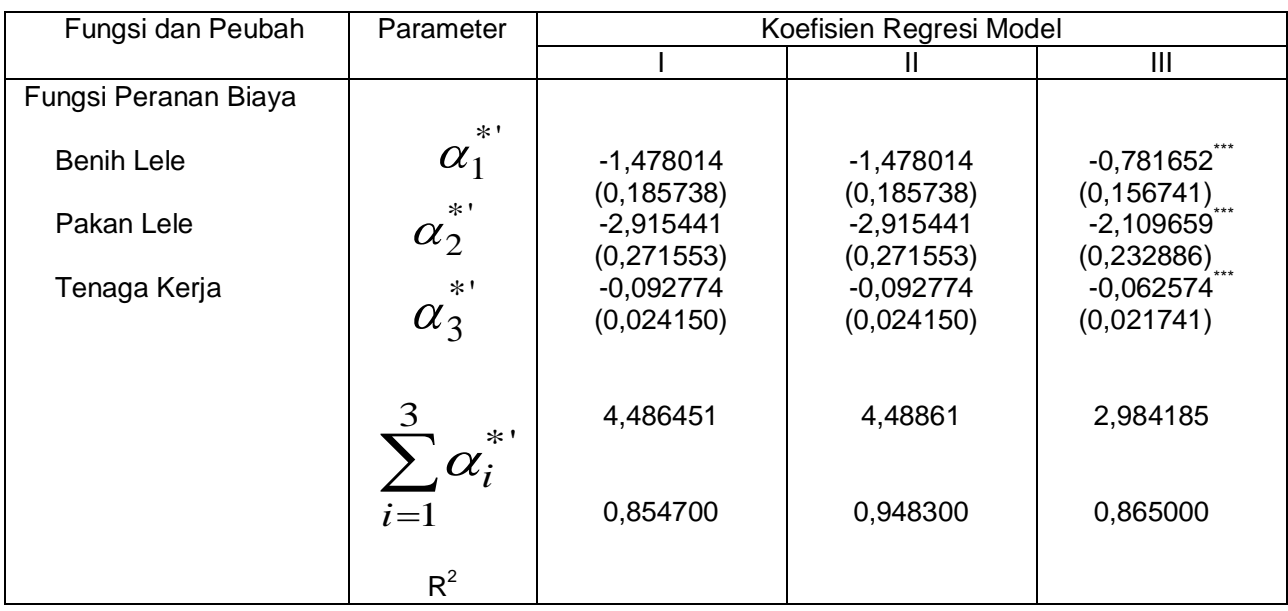

Keterangan:

1. Model I : pendugaan dengan OLS;

Model II : pendugaan dengan metoda Zellner tanpa restriksi kesamaan $\alpha_{i}^{*}=\alpha_{i}^{*}$;

Model III : pendugaan dengan metoda Zellner dengan restriksi kesamaan $\alpha_{i}{ }^{*}=\alpha_{i}{ }^{*}$

2. Angka dalam kurung adalah simpangan baku;

3. * : nyata pada taraf kepercayaan $90 \%$;

** : nyata pada taraf kepercayaan $95 \%$

*** : nyata pada taraf kepercayaan $99 \%$

Kesalahan penaksiran standar (standar error) yang dihasilkan pada masingmasing model memperlihatkan bahwa penggunaan metoda Zellner memberikan nilai standar error yang lebih kecil untuk seluruh parameter yang diduga jika dibandingkan dengan metoda OLS. Hal ini menunjukkan bahwa penggunaan metoda Zellner tersebut relatif lebih baik dan teliti untuk pendugaan parameter yang diduga, sehingga pembahasan mengenai fungsi peranan biaya (share factor) selanjutnya akan lebih ditekankan pada model yang menggunakan metoda Zellner.

Fungsi peranan biaya (share factor) merupakan sumbangan (contribution) suatu masukan tidak tetap terhadap keuntungan. Berdasarkan hasil perhi- 
tungan diketahui bahwa pada selang kepercayaan 99\% untuk kondisi aktual (Model II, Tabel 1), pengaruh peningkatan penggunaan benih lele dan pakan lele ternyata mengakibatkan penurunan yang relatif besar terhadap keuntungan, dimana peningkatan $10 \%$ masing-masing untuk penggunaan benih lele dan pakan lele akan mengakibatkan penurunan keuntungan berturut-turut sebesar 16,98 dan $12,91 \%$.

Kondisi di atas dapat dipahami karena untuk memperoleh tingkat keuntungan yang maksimum, petani lele harus menggunakan benih lele yang memiliki mutu baik dari jenis spesies lele yang kompetitif dalam harga jual dan korbanan biaya produksi. Selain itu, untuk memperoleh produksi lele ukuran konsumsi dengan cepat, maka lele-lele tersebut harus diberi pakan secara teratur dan tepat, sehingga dengan sendirinya akan mempengaruhi besarnya pengeluaran untuk pembelian pakan tersebut.

Peningkatan penggunaan masukan tidak tetap tenaga kerja manusia berpengaruh relatif lebih kecil terhadap keuntungan, dimana peningkatan $10 \%$ upah tenaga kerja manusia hanya akan mengakibatkan penurunan keuntungan sebesar $0,62 \%$.

\section{Elatisitas permintaan masukan dan penawaran keluaran}

Mengingat fungsi permintaan masukan dan penawaran keluaran merupakan turunan dari fungsi keuntungan dan peranan biaya (share factor), maka pendugaan elastisitas harga dalam penelitian ini harus diinterpretasikan mutatis mutandis pada fungsi keuntungan output unit price (OUP), yang berarti mempunyai perbedaan dengan interpretasi elastisitas ceteris paribus pada fungsi produksi (Lau dan Yotopaulus, 1972).
Pendugaan elatisitas permintaan dari fungsi produksi yang telah umum dikenal menunjukkan suatu perubahan dari peubah tak bebas atas perubahan dari suatu peubah bebas, sementara peubahpeubah lainnya dianggap konstan (ceteris paribus). Sedangkan pendugaan elastisitas yang diperoleh dari fungsi permintaan yang diturunkan dari fungsi keuntungan yang dinormalkan menunjukkan perubahan peubah tak bebas yang diakibatkan oleh perubahan suatu peubah bebas, sementara peubah-peubah lainnya menyesuaikan dengan kondisi keuntungan maksimum jangka pendek (mutatis mutandis) (Saragih, 1980, 1982; Sugianto, 1982).

Tabel 2 memperlihatkan nilai elastisitas permintaan masukan tidak tetap dan penawaran keluaran pada kondisi aktual dari usaha budidaya lele dalam kolam di Kabupaten Tulung Agung, Jawa Timur. Dari Table 2 tersebut diketahui bahwa pada kondisi aktual, harga lele mempunyai respon yang positif terhadap penawaran dari lele. Perubahan harga lele sebesar $10 \%$ akan merubah penawaran lele (perubahan searah) sebesar $44,65 \%$. Dengan demikian dapat dikatakan bahwa penawaran lele bersifat elastis.

Keadaan yang berbeda ditemukan bahwa penawaran lele bersifat elatis terhadap perubahan harga masukan tidak tetap. Kenaikan 10\% harga masukan tidak tetap benih lele dan pakan lele akan menurunkan penawaran masing-masing sebesar 27,85 dan $14,78 \%$. Hal ini dapat disebabkan benih lele dan pakan lele merupakan masukan tidak tetap yang sangat diperlukan dalam usaha budidaya lele ini. Akan tetapi perubahan penawar-an lele dapat dikatakan bersifat inelastis terhadap perubahan upah tenaga kerja manusia, dimana kenaikan $10 \%$ upah tenaga kerja manusia hanya akan mengakibatkan penurunan penawaran lele sebesar $0,92 \%$. 
Tabel 2. Elastisitas permintaan masukan tidak tetap dan penawaran keluaran usaha budidaya pembesaran lele dalam kolam pada kondisi aktual')

\begin{tabular}{|l|r|r|r|r|}
\hline \multirow{2}{*}{ Uraian } & \multicolumn{4}{|c|}{ Harga } \\
\cline { 2 - 5 } & \multicolumn{1}{|c|}{ Keluaran } & \multicolumn{1}{|c|}{ Benih Lele } & \multicolumn{1}{|c|}{ Pakan Lele } & Tenaga Kerja \\
\hline $\begin{array}{l}\text { Penawaran } \\
\text { Keluaran }\end{array}$ & 4,465171 & $-2,785124$ & $-1,478416$ & $-0,092675$ \\
$\begin{array}{l}\text { Permintaan } \\
\text { Masukan: }\end{array}$ & 5,485473 & $-3,785124$ & $-1,478416$ & $-0,092675$ \\
$\begin{array}{l}\text { - Benih Lele } \\
\text { - Pakan Lele } \\
\text { - Tenaga Kerja }\end{array}$ & 5,485473 & $-2,785124$ & $-2,478416$ & $-0,092675$ \\
& 5,485473 & $-2,785124$ & $-1,478416$ & $-1,092675$ \\
\hline
\end{tabular}

Keterangan : ' diturunkan dari Model II (Tabel 1.)

Perubahan harga lele menimbulkan perubahan permintaan terhadap masukan tidak tetap yang sangat elastis. Peningkatan $10 \%$ harga lele akan menyebabkan peningkatan permintaan terhadap masukan tidak tetap benih lele, pakan lele dan tenaga kerja manusia masing-masing sebesar $54,85 \%$. Hal ini mungkin disebabkan karena adanya peningkatan harga lele akan mendorong petani lele untuk meningkatkan produksinya, sehingga permintaan akan masukan-masukan tidak tetap akan meningkat pula.

Elastisitas harga sendiri (own price elasticity) untuk masing-masing masukan tidak tetap menunjukkan nilai yang lebih besar dari satu, kecuali untuk tenaga kerja manusia yang memiliki nilai elastisitas mendekati satu. Kenaikan harga masukan tidak tetap benih lele dan pakan lele sebesar $10 \%$ akan menyebabkan penurunan terhadap permintaan masukan tersebut masing-masing sebesar 37,85 dan $24,78 \%$.

Elastisitas harga silang yang menggambarkan permintaan masukan akibat perubahan harga masukan lainnya digunakan untuk melihat sifat komplemen atau substitusi dari masukan, yaitu apabila tanda elstisitas tersebut negatif maka bersifat komplemen dan bila bertanda positif maka bersifat substitusi (Sukirno, 1985). Penentuan sifat komplemen atau substitusi antar masukan pada usaha budidaya lele dalam kolam merupakan hal yang sulit. Walaupun demikian dengan melihat tanda dari dugaan elastisitas, diharapkan mampu menggambarkan sifat hubungan tersebut.

Berdasarkan tanda dari elastisitas harga silang (cross price elasticities), hubungan antar masukan kesemuanya memiliki tanda negatif yang berarti antar masukan diduga hubungannya bersifat komplemen. Sifat komplemen antar masukan ini berarti bahwa peningkatan penggunaan suatu masukan akan diikuti peningkatan dalam penggunaan masukan lainnya.

Elastisitas harga silang pada kondisi aktual untuk masukan tidak tetap dapat diuraikan sebagai berikut: (1) kenaikan $10 \%$ harga benih lele akan menyebabkan penurunan permintaan terhadap masukan pakan lele dan tenaga kerja manusia masing-masing sebesar 27,85\%; (2) kenaikan $10 \%$ harga pakan lele akan menyebabkan penurunan permintaan terhadap masukan benih lele dan tenaga kerja manusia masing-masing sebesar 14,78\%; dan (3) kenaikan 10\% upah tenaga kerja manusia akan menyebabkan penurunan permintaan terhadap masukan benih lele dan pakan lele masing-masing sebesar $0,92 \%$.

Pada kondisi yang optimal (Tabel 1), yaitu pada saat tercapainya keuntungan maksimum (penurunan dari model III), pengaruh perubahan harga lele terhadap penawaran lele relatif lebih kecil dibandingkan pada kondisi aktual, dimana perubahan $10 \%$ harga lele hanya menye- 
babkan perubahan penawaran (perubahan searah) sebesar 29,84\%. Dengan demikian dapat dikatakan bahwa penawaran lele bersifat elastis.

Perubahan harga masukan tidak tetap upah tenaga kerja manusia terhadap penawaran lele relatif bersifat inelastis, sedangkan pengaruh perubahan harga benih lele dan pakan lele terhadap penawaran lele dapat dikatakan relatif sangat elastis. Hal ini dapat dilihat ber- dasarkan koefisien elastisitasnya, diketahui bahwa kenaikan $10 \%$ harga masukan tidak tetap upah tenaga kerja manusia akan menyebabkan penurunan terhadap penawaran lele sebesar $0,63 \%$, sedangkan kenaikan $10 \%$ pada harga benih lele dan pakan lele masing-masing akan memberikan pengaruh yang lebih besar terhadap penurunan penawaran lele, yaitu masing-masing sebesar 21,09 dan $7,82 \%$.

Tabel 3. Elastisitas permintaan masukan tidak tetap dan penawaran keluaran usaha budidaya lele dalam kolam pada kondisi optimal

\begin{tabular}{|l|r|r|r|r|}
\hline \multirow{2}{*}{\multicolumn{1}{|c|}{ Uraian }} & \multicolumn{3}{c|}{ Harga } \\
\cline { 2 - 5 } & \multicolumn{1}{|c|}{ Keluaran } & \multicolumn{1}{c|}{ Benih Lele } & Pakan Lele & Tenaga Kerja Manusia \\
\hline Penawaran Keluaran & 2,973185 & $-2,145216$ & $-0,781652$ & $-0,072634$ \\
Permintaan Masukan: & 3,963248 & $-3,145216$ & $-0,781652$ & $-0,072634$ \\
- Benih Lele & 3,963248 & $-2,145216$ & $-1,781652$ & $-0,072634$ \\
- Pakan Lele & 3,963248 & $-2,145216$ & $-0,781652$ & $-1,072634$ \\
- Tenaga Kerja & & & \\
$\quad$ Manusia & \multicolumn{2}{|l}{} & & \\
\hline
\end{tabular}

Perubahan harga lele menimbulkan perubahan permintaan terhadap masukan tidak tetap yang sangat elastis. Peningkatan $10 \%$ harga lele akan menyebabkan peningkatan terhadap permintaan masukan tidak tetap benih lele, pakan lele dan tenaga kerja manusia masing-masing sebesar $39,63 \%$.

Elastisitas harga sendiri (own price elasticities) untuk masukan tidak tetap benih lele dan pakan lele menunjukkan nilai yang lebih besar dari satu, yang berarti bahwa kenaikan 10\% harga benih lele dan pakan lele akan menyebabkan penurunan terhadap permintaan benih lele dan pakan lele masing-masing sebesar 31,45 dan $17,82 \%$. Elastisitas harga sendiri (own price elasticities) untuk masukan tidak tetap tenaga kerja manusia memiliki nilai yang mendekati satu (elastisitas unit), yang berarti bahwa kenaikan upah tenaga kerja manusia akan menyebabkan penurunan permintaan tenaga kerja manusia dengan proporsi yang sama.
Berdasarkan tanda dari elastisitas hubungan antar masukan pada kondisi optimal semuanya bersifat komplemen, yang berarti peningkatan penggunaan suatu masukan akan diikuti oleh peningkatan dalam penggunaan masukan lain. Elastisitas harga silang untuk masingmasing masukan tidak tetap pada kondisi optimal (keuntungan maksimum) dapat diuraikan sebagai berikut: (1) kenaikan $10 \%$ harga benih lele akan menyebabkan penurunan permintaan terhadap pakan lele dan tenaga kerja manusia masingmasing sebesar 21,45\%; (2) kenaikan $10 \%$ harga pakan lele akan menyebabkan penurunan terhadap permintaan benih lele dan tenaga kerja manusia masingmasing sebesar $7,82 \%$; dan (3) kenaikan $10 \%$ upah tenaga kerja manusia akan menyebabkan penurunan terhadap permintaan benih lele dan pakan lele masingmasing sebesar $0,72 \%$. 


\section{Kesimpulan dan Saran}

Kesimpulan

a. Dari penurunan fungsi permintaan masukan tidak tetap dan penawaran keluaran didapatkan bahwa harga lele bersifat elastis dan responsif terhadap perubahan harga lele, benih lele dan pakan lele tetapi inelastis terhadap perubahan upah tenaga kerja manusia. Harga lele memberikan pengaruh positif terhadap permintaan masukan tidak tetap dan penawaran keluaran. Pengaruh positif perubahan harga lele tersebut lebih besar dari pengaruh negatif pada perubahan harga masukan tidak tetap.

b. Peningkatan harga lele akan menimbulkan permintaan terhadap masukan-masukan tidak tetap (benih lele, pakan lele dan tenaga kerja manusia) usaha budidaya lele menjadi elastis dan responsif.

c. Elastisitas harga silang antara masing-masing masukan tidak tetap berkisar antara 0,092675 sampai dengan 2,785124. Sedangkan elastisitas permintaan harga sendiri untuk masing-masing masukan tidak tetap adalah benih lele sebesar 3,785124 ; pakan lele sebesar 2,478416; dan tenaga kerja manusia sebesar 1,092675 .

\section{Saran}

Melihat kenyataan bahwa pengaruh harga lele bersifat elastis dan responsif terhadap perubahan permintaan masukan tidak tetap maupun penawaran keluaran (lele), maka para pembuat kebijakan hendaknya turut berperan serta dalam menjaga stabilitas harga lele di tingkat petani lele.

\section{Daftar Pustaka}

Biswanger, H. 1974. A cost function approach to the measurement of factor demand elasticities and at elasticities of substitution. American J. Agro Economic. 56:377-386.

Chand, R. and J.L. Kaul. 1986. A note use of the Cobb-Douglas profit function. American J. of Agricultural Economic, 68: 1962-1964.

Lau, L.J. and P.A. Yotopaulus. 1971. A test for realtive efficiency and application to Indian agriculture. American Economic Review. 61: 44-109.

.1972. Profit supply and demand functions. American J. Agro Economic. 54: 11-18.

.1979. The methodological framework of profit functions. Food Research Institute Studies. USA. 1 (17):11-22.

Nazir, M. 1988. Metode penelitian. Ghalia Indonesia. Jakarta. 622 p.

Saragih, B 1980. Economic organization, size and relative efficiency: the case of oil palm in Northern Sumatera, Indonesia. Unpublished Ph.D. dissertation, Departement Economics and Business, North Carolina State University, Raleigh. . 1982. Skala usaha pada perkebunan kelapa sawit dan implikasinya terhadap pengembangan perkebunan rakyat. J. Agro Ekonomi. 2(1): 56-62

Sugianto, T. 1982. The relative economic efficiency of irrigated rice farm, West Java. Unpublished Ph.D. dissertation University of Illionois at Urbana-Champaign.

Sukirno, S. 1985. Teori ekonomi mikro. Fakultas Pertanian. Institut Pertanian Bogor. Bogor. $378 \mathrm{p}$.

Varian, H.R. 1978. Microeconomic analysis. W.W. Norton \& Company, New York. 